\title{
Eurasian Interpretation of Alexander Nevsky in the Works of Vernadsky and Klepinin
}

\author{
R. A. Sokolov
}

For citation: Sokolov R. A. Eurasian Interpretation of Alexander Nevsky in the Works of Vernadsky and Klepinin. Vestnik of Saint Petersburg University. History, 2019, vol. 64, iss. 4, pp.1419-1428. https://doi.org/10.21638/11701/spbu02.2019.416

Within twenty years after the 1917 revolution, the historical memory of Alexander Nevsky had died away in the Soviet Russia due to a strong association between his veneration and the Romanov dynasty. By contrast, scholars of the émigré milieu regularly referred to the prince's historical and spiritual experience. However, even abroad, although the name of the prince occurred in fundamental works and scholarly articles, only one book on his biography was published throughout this period (1927). It is the work by N. Klepinin, whose life happened to be closely connected with the Eurasianist movement. This circumstance determined the rapprochement with the Soviet special services, participation in special operations, homecoming and, eventually, death. The dramatic fate of Klepinin should not diminish the merits of his main and, unfortunately, the only major historical work. The comparison of this work with those of G. Vernadsky and the archives of the scholar, published and introduced by A. Dvornichenko, enable us to trace the ideological connections of two émigré historians. Their contemporaries, in particular, G. Fedotov and I. Il'in, referred to the similarity of the approaches of both historians. Indeed, they had similar views on many developments and historical processes (the interpretation of Mongolian suzerainty, the role of the Orthodox Church in the national history etc). Living in the United States G. Vernadsky suggested inviting Klepinin to contribute to a large collective work on Church history. The fact that Vernadsky also sympathized with the Eurasians, although he objected to their involvement in political processes, can account for the affinity in the interpretation of historical events.

Keywords: historiography, G. V. Vernadsky, Eurasianism, Alexander Nevsky, N. A. Klepinin.

Roman A. Sokolov - Doctor in History, Professor, St. Petersburg State University, 7-9, Universitetskaya nab., St. Petersburg, 199034, Russian Federation; r.sokolov@spbu.ru

Роман Александрович Соколов - д-р ист. наук, проф., Санкт-Петербургский государственный университет, Российская Федерация, 199034, Санкт-Петербург, Университетская наб., 7-9; r.sokolov@spbu.ru

The research was supported by the grant of Russian Science Foundation No. 17-18-01168 "Historical modifications of the biblical socio-political doctrine and religious fundamentals of the political and legal thinking in Russian Empire".

Исследование подготовлено в рамках проекта РНФ № 17-18-01168 «Модификации социально-политического учения Библии в истории и религиозные основания политико-правовой мысли Российской империи».

(c) Санкт-Петербургский государственный университет, 2019 


\section{Евразийская интерпретация Александра Невского в трудах Вернадского и Клепинина}

\section{Р. А. Соколов}

Для цитирования: Sokolov R.A. Eurasian Interpretation of Alexander Nevsky in the Works of Vernadsky and Klepinin // Вестник Санкт-Петербургского университета. История. 2019. Т. 64. Вып. 4. С. 1419-1428. https://doi.org/10.21638/11701/spbu02.2019.416

В первые два десятилетия после революции 1917 г. историческая память об Александре Невском в Советской России оказалась в забвении по причине слишком четкой связи его почитания (прежде всего церковного) с династией Романовых. В противоположность этому в среде эмигрантов обращение со стороны ученых (историков и философов) к историческому и духовному опыту князя оказалось достаточно востребованным. Однако и за границей, несмотря на то что имя князя встречалась в фундаментальных работах и отдельных статьях, в этот период была опубликована лишь одна книга, посвященная его биографии (1927). Автором этого труда стал Н.А.Клепинин, жизнь которого в то самое время оказалась тесно связанной с движением евразийцев. Данное обстоятельство стало отправной точкой для его сближения с советскими спецслужбами, участия в спецоперациях, возвращении на Родину и, как следствие, гибели. Драматическая судьба Н.А. Клепинина не должна заслонять значения главной и, к сожалению, единственной его крупной исторической работы. Сопоставление этого труда с работами Г.В.Вернадского и архивным наследием ученого, опубликованным и введенным в научный оборот А.Ю.Дворниченко, позволяет выявить идейные связи двух историков-эмигрантов. На связь подходов обоих историков указывали и современники, в частности Г. П. Федотов и И.Н. Ильин. Действительно, им была присуща схожесть трактовок многих событий и процессов в целом (взгляд на монгольскую зависимость, оценка роли православия в отечественной истории, некоторые частные вопросы и т.д.). Уже будучи в США, Г. В.Вернадский предполагал привлечь Н. А. Клепинина к написанию крупного коллективного труда по истории церкви. В значительной мере такая схожесть в трактовке исторических событий объясняется тем, что Г.В.Вернадский тоже симпатизировал евразийцам, хотя и был противником их участия в политических процессах.

Ключевые слова: историография, Г.В.Вернадский, евразийство, Александр Невский, Н. А. Клепинин.

Over the first two decades of the Soviet era the name of Alexander Nevsky had been forgotten. This was caused both by the attitudes of the new regime to the history of old pre-revolutionary Russia and its national heroes, and by the fact that Iaroslavich appeared to have been a highly "inconvenient person" for the ideology of that time as he was, first, a ruling prince (allegedly, an exploiter) and, second, was worshipped as a saint, closely associated with the Romanov dynasty ${ }^{1}$. This connection was established in the $18^{\text {th }}$ century when the relics of the hero of the Battle on the Ice were transferred to St. Petersburg. It became stronger in the $19^{\text {th }}$ century when three out of the six emperors in power would celebrate their name day on the same day with him; since 1724 by the order of Peter I this day was timed to coincide with August 30, the anniversary of the Nystad peace treaty ${ }^{2}$.

${ }^{1}$ Sokolov R.A. Aleksandr Nevskii v sovetskoi dovoennoi istoriografii. Aleksandr Nevskii i Ledovoe poboishche. Materialy nauchnoi konferentsii, posviashchennoi 770-letiiu Ledovogo poboishcha. SanktPeterburg, 7 aprelia 2012 g. / eds Y. V. Krivosheev, R. A. Sokolov. St. Petersburg, 2014. P. 162-163.

2 Shenk F. Aleksandr Nevskii v russkoi kul'turnoi pamiati: Sviatoi, pravitel', natsional'nyi geroi (12632000). Moscow, 2007. P. 130-237. 
In the émigré circles, the figure of the prince, on the contrary, more than once had come to the fore and public attention. In the foreign lands Russian scholars reinterpreted the historical experience of national heroes and saintly ascetics, whose activities were intertwined with the historical developments in the country researchers had to abandon. One of such studies was the book of G. P. Fedotov ${ }^{3}$ focused on Russian sanctity, with special emphasis placed on the personality of Alexander Nevsky. It is noteworthy that in the late 1930s not long before the release of the well-known movie by Sergei Eisenstein (which, of course, Fedotov knew nothing about) the author of the book in one of his journalistic works analyzed the stubborn reluctance of the Soviet ideology to draw on the historical memory of the Russian prince 4 .

In terms of integrated approach towards the study of the biography of Iaroslavich, the work "Sviatoi i blagovernyi velikii kniaz' Aleksandr Nevskii" (Holy and Pious Grand Prince Alexander Nevsky) by Nikolai Andreevich Klepinin (1899-1941), published in Paris in 1927, was believed to be the most significant in the milieu of the first wave of émigrés.

Despite the painstaking efforts, it is not easy to provide a detailed account of the life of this historian, a person of cruel fate, whose talent for certain reasons was not destined to flower to the full. Moreover, the information about him available in bibliographies and reference books is not always reliable ${ }^{5}$. Meanwhile, Klepinin's book about Alexander Nevsky, for the first time published around a century ago, is quite popular and has been reprinted more than once within the last decade. This study has all the characteristic features of a monograph, such as: scholarly bibliographic apparatus, relevant evidence base, etc. Yet, N. A. Klepinin's style of writing is rather unusual since the author actually created a new life story of the prince aimed at gaining the confidence of modern readers, with the main arguments being backed with the sources. The study received a warm welcome on the part of the émigré circles. In particular, G. P. Fedotov, who, as we have noticed, took an interest in the above-mentioned subject, claimed that this book, relatively modest in size, was an "insightful historical account" of the life of our great ancestor Alexander Nevsky 6 . This paper is an attempt to shed light on the major events in the life of the author of this workwritten more that ninety years ago.

N. A. Klepinin was born on 17 January 1899 in the city of Piatigorsk in the family of an architect ${ }^{7}$; his mother was a relative of Zinaida Gippius ${ }^{8}$. Klepinin joined the Voluntary Army during the Civil War and like many thousands (or even millions) of Russian exiles had to leave the country in 1920. At first, he settled in Belgrade ${ }^{9}$ and took part in the Rus-

${ }^{3}$ Fedotov G. P. Sviatye Drevnei Rusi. Moscow, 1990. - The first edition was published in 1931 by the publishing house YMCA-PRESS.

${ }^{4}$ Fedotov G.P. Karl Marks i Aleksandr Nevskii // Voprosy filosofii. 1990. No. 8. P.154. — First published in 1937, in the newspaper "Novaia Rissiia" (New Russia).

5 The bibliographic directory by A. Foster gives inaccurate information about the patronymic of N.A. Klepinin - Alexandrovich. See: Bibliografiia russkoi zarubezhnoi literatury 1918-1968. Compiler A. Foster. Vol. I: A-K. Boston, 1970. P. 622.

${ }^{6}$ Fedotov G.P. N. A. Klepinin. Sviatoi i blagovernyi velikii kniaz' Aleksandr Nevskii. YMCA PRESS, Paris // Sovremennye zapiski. Vol.36. Paris, 1928. P. 546.

7 Russkie pisateli emigratsii. Biograficheskie svedeniia i bibliografiia ikh knig po bogosloviiu, religioznoi filosofii, tserkovnoi istorii i pravoslavnoi kul'ture 1921-1972. Comp. by N.Zernov. Boston, 1973. P. 67.

8 Zhizn' i zhitie sviashchennika Dmitriia Klepinina. 1904-1944. Moscow, 2004. P. 10.

9 Pashuto V.T. Russkie istoriki-emigranty v Evrope. Moscow, 1992. P. 140. 
sian Student Christian Movement (RSCM $)^{10}$ set up in Yugoslavia in 1921. Two years later (in 1923) the first congress of the organization took place in Czechoslovakia. The movement was headed by V. V. Zen'kovsky ${ }^{11}$ who, together with N. A. Klepinin, attended the religious-philosophic society established in Berlrade in $1922^{12}$. In September 1925, the third conference of RSCM was held in Hopov. N. A. Klepinin, as a chairman of Belgrade society, gave a talk at the conference, having touched upon the issue of Orthodox brotherhoods. The paper gave rise to a heated debate regarding the existing forms of brotherhoods ${ }^{13}$.

However, it was the capital of France that remained the centre of Russian emigration; that is why N.A. Klepinin as well as many other Russian exiles moved to Paris in 1926 where he started working for the journal "Put" (The Way) straight away ${ }^{14}$. His article "Bratstvo i puti pravoslavnogo studencheskogo dvizheniia" (Brotherhood and Directions of the Orthodox Student Movement) was published in the third issue of the journal in the same year (1926) ${ }^{15}$; the next - fourth — issue contained one more article "Svetloi pamiati igumenii Ekateriny" (In the Blessed Memory of the Mother Superior Ekaterina) ${ }^{16}$. It is noteworthy that the latter was signed only with the initials N.K. However, both the style of the text and the data from N. Zernov's reference book (which, by the way, published the same article with a slightly different heading "Pamiati igumen'i Ekateriny (Efimovskoi)" (In the Memory of the Mother Superior Ekaterina (Efimovskaia)) indicate the authorship of N. A. Klepinin ${ }^{17}$.

N.A. Klepinin seems to have started working on the book straight on arrival for it was released by the publishing house YMCA-PRESS as early as in 1927. It should be pointed out that the book entitled "Sviatoi i blagovernyi velikii kniaz' Aleksandr Nevskii"doesn't provide information about the year of publication although it can be easily identified through the "Katalog russkikh knig zarubezhnykh izdanii 1990-1991" (Catalogue of Russian books published abroad 1990-1991) - the advertising pamphlet of YMCA-PRESS"18. Visually, the book did not look very attractive: plain gray paperback with yellow pages and indiscreet print. However, despite this modest form, the book did draw the attention of the public.

To a certain extent, the fact that N.A. Klepinin at that time joined the Eurasionist movement ${ }^{19}$ and even became one of its active participants can account for this. Needless to say, the ideas and nature of the Eurasianism are beyond the scope of this article, so I will only make mention of the fact that Eurasians did not demonize bolshevism and found Russian revolution historically inevitable, incurring the anger of "implacable" Russian émigrés. As for N. A. Klepinin, his affiliation with the movement could not but have

10 Russkie pisateli emigratsii... P. 67.

${ }^{11}$ Kostikov V. V. Ne budem proklinat' izgnan'e... Puti i sud'by russkoi emigratsii. Moscow, 1990. P. 249.

12 Zen'kovskii V. V. Moi vospominaniia ob o. Dmitrii Klepinine // Zhizn' i zhitie sviashchennika Dmitriia Klepinina. 1904-1944. Moscow, 2004. P. 165.

13 Zander L. Iz religioznoi zhizni russkoi molodezhi. II. S"ezd v Khopove // Put'. Organ russkoi religioznoi mysli. Kn. 1. Moscow, 1992. P. 233-234.

${ }_{14}$ Pashuto V.T. Russkie istoriki-emigranty v Evrope. P. 140.

${ }^{15}$ Klepinin N.A. Bratstvo i puti pravoslavnogo studencheskogo dvizheniia // Put'. Organ russkoi religioznoi mysli. 1926. No.3. P. 127-133.

${ }^{16}$ N.K. [Klepinin N.A.] Svetloi pamiati igumen'i Ekateriny // Put'. Organ russkoi religioznoi mysli. 1926. No. 4. P. 166-171.

17 Russkie pisateli emigratsii... P. 67.

18 Katalog russkikh knig zarubezhnykh izdanii 1990-1991. Paris, 1991. P. 14.

19 Russkie pisateli emigratsii... P 67. 
an impact on his work. In particular, the influence of Georgy Vladimirovich Vernadsky, a well-established historian and researcher, who sympathized with the ideas of Eurasians, was especially apparent. The life and works of the latter are often compared with the ones of B.D. Grekov, another authority in the field of historical science, who was destined to remain the informal leader of Soviet historians for many years. It is quite understandable as the life stories of both scholars have a lot in common and their contribution to science is thought to be of equal worth.

Of course, the scholarly heritage of G. V. Vernadsky and N. A. Klepinin cannot be compared in the same manner. At the same time, when it comes to the interpretation of the role of Alexander Nevsky in Russian history, it is impossible to miss the obvious similarity in their arguments, which was rooted, first, in the affinity between their worldviews and, second, in the fact that the latter modeled his view on the opinion of the former. Indeed, they both belonged to the Eurasianist movement and had an inclination for religious quest $^{20}$. Moreover, G. V. Vernadsky certainly knew Klepinin as a competent researcher as he mentioned his name, alongside those of P.N.Savitsky, N.A.Berdiaev, G.P. Fedotov, V.N. Il'in and others, in his correspondence as one of the prospective contributors to the prearranged (but never accomplished) collection "Tserkov' i sotsial'nyi stroi” (The Church and Social System) intended to support the Church in the Soviet Russia ${ }^{21}$. It should be pointed out that the letters of D. A. Klepinin (the brother of N.A. Klepinin) contain information about his brother collecting evidence of the prosecution of believers in the USSR at that time $e^{22}$.

The research article of G. V.Vernadsky "Dva podviga Aleksandra Nevskogo" (Two Feats of Alexander Nevsky) ${ }^{23}$, published in the "Evraziiskii vremennik" (Eurasian Chronicle), compares the activities of the prince and his contemporary Daniel of Galicia. The author comes to the conclusion that the Alexander's decision to submit to the Orient in order to give a rebuff to the Occident was the only possible solution ${ }^{24}$. This short study proved to be of great importance both for the science and for the future reputation of the prince in the eyes of the society. This can be confirmed by the numerous modern republications and electronic versions of the article, on the one hand, and by the fact that the scholars still use the conceptual model of this subject area suggested by G. V. Vernadsky ${ }^{25}$, on the other. The same model was also developed and used by Vernadsky in other works covering this period of Russian history.

Returning to the study of N.A. Klepinin, we will examine the affinity between some of his arguments with the approach suggested by his authoritative colleague, and quote some statements from both researches. "The incorporation of Northern Rus' into the Tatar-Mongol Empire made it part of the world history" - claimed N. A. Klepinin ${ }^{26}$.

${ }^{20}$ About the religiosity of G. V. Vernadsky see: Dvornichenko A. Yu. Russkii istorik Georgii Vernadskii. Puteshestvie v mire liudei, idei i sobytii. St. Petersburg, 2017. P. 129-131.

${ }^{21}$ Ibid. P. 228.

${ }^{22}$ Klepinin D.A. Pis'ma Dmitriia Klepinina k S.S. Shidlovskoi 1 iiulia 1930 g. - 25 marta 1931 g. // Zhizn' i zhitie sviashchennika Dmitriia Klepinina. 1904-1944. Moscow, 2004. P.94-95, 141, note 2.

${ }^{23}$ See one of the modern republications: Vernadskii G. V. Dva podviga Aleksandra Nevskogo // Nash sovremennik. 1992. No. 3. P.151-164.

${ }^{24}$ See a detailed analysis of the article: Dvornichenko A. Yu. Russkii istorik Georgii Vernadskii. P. 129.

25 Begunov Iu. K. Vybor Aleksandra Nevskogo i znachenie Vybora dlia sudeb russkoi gosudarstvennosti tsivilizatsii. Sviatoi Aleksandr Nevskii // Sbornik statei k 760-letiiu Nevskoi bitvy, ispolniaiushchemusia v 2000 godu. /ed. by Y. K. Begunov. Ust'-Izhora, 1999. P. 6-17.

26 Klepinin N. A. Sviatoi i blagovernyi velikii kniaz' Aleksandr Nevskii. Moscow, 1993. P. 7. 
"Due to the 'Mongolian yoke' Russia got closely bound to the steppe centre and the mainland provinces of Asia" - argued G. V.Vernadsky in the "Evraziiskii vremennik" in $1927^{27}$.

Nikolai Andreevich attached great importance to the role of the Church in the history of ancient Rus. This is a consistent thread running throughout his book. G. V. Vernadsky also adhered to the same opinion: "Orthodoxy is the cultural identity of Russia" — he stated in one of the articles ${ }^{28}$.

However, one could reasonably argue that it was typical of the Eurasians in general to attach great importance to the Tatar impact on the historical process in Russia, with this impact seen mostly from the positive side. The ideologists of the movement also believed the Orthodox Church to be one of the major factors which influenced the history of Rus$\operatorname{sia}^{29}$. Thus, these statements of G. V. Vernadsky and N.A. Klepinin appear to be in line with the general Eurasian trend. At the same time, we can demonstrate a number of single debatable issues where the above-mentioned researches also agree with each other. For example, in contrast to the Soviet scholar A. N. Nasonov, they both believed that legendary Kotlubei, referred to in the chronicle with regard to the veche riots in the North-East of Russia in $1262^{30}$, was in fact not Khan Kublai ${ }^{31}$ but a tax collector. Moreover, the historians did not acknowledge the role of Alexander Iaroslavich in the organization of these riots ${ }^{32}$.

As it was already mentioned, the release of the book about Alexander Nevsky did not go unnoticed. It received two reviews of rather authoritative scholars. It is noteworthy that both of them specifically highlighted the influence of G. V. Vernadsky.

G. P. Fedotov in "Sovremennye zapiski" (Contemporary Notes) gave a generally positive feedback on this work, with the exception of the criticism of the unreasonably lavish attention paid by Klepinin to the personality of Genghis Khan. Moreover, G. P. Fedotov pointed out the tendency of the author to echo G. V. Vernadsky featuring Alexander Nevsky as no less than a "Eurasian hero" 33 .

One more review written by V.N.Il'in was published in the $8^{\text {th }}$ issue of the journal "Put" (The Way) in $1927^{34}$. The author emphasized that he had no intention of "examining the book from the historico-critical point of view" since "the objective of the book, which seemed to have been purely historiosophical, was successfully realized by the author". At the same time, V. N. Il'in stressed that the major merit of the study was "a subtle perception and accurate interpretation of the image of a national saint." The review once

27 Vernadskii G. V. Mongol'skoe igo v russkoi istorii // Nash sovremennik. 1992. No. 3. P. 160.

28 Vernadskii G. V. Dva podviga Aleksandra Nevskogo. P. 154.

29 See, for example: Savitskii P. N. Kontinent Evraziia. Moscow, 1997. P. 27-36, 51, 82-83, 92-93, 125, $195,281,282,332-334$.

30 Polnoe sobranie russkikh letopisei. T. I. Lavrent'evskaia letopis'. Moscow, 1997. Col. 476.

31 Vernadskii G. V. Mongoly i Rus'. Tver; Moscow, 1997. P. 167; Klepinin N. A. Sviatoi i blagovernyi velikii kniaz’ Aleksandr Nevskii. P.92. - Compare, for example.: Nasonov A. N. Mongoly i Rus'. Istoriia tatarskoi politiki na Rusi // Nasonov A. N. "Russkaia zemlia” i obrazovanie territorii Drevnerusskogo gosudarstva. Istoriko-geograficheskoe issledovanie. Mongoly i Rus'. Istoriia tatarskoi politiki na Rusi. St. Petersburg, 2006. P. 254-256.

32 Vernadskii G. V. Mongoly i Rus'. P. 167-168; Klepinin N.A. Sviatoi i blagovernyi velikii kniaz’ Aleksandr Nevskii. P. 92.

33 Fedotov G. P. N. A. Klepinin. Sviatoi i blagovernyi velikii kniaz’ Aleksandr Nevskii. P. 548.

34 A. Foster in the directory does not accurately indicate the year of publication of this issue of the journal "Put" (The Way) - 1928 (Bibliografiia russkoi zarubezhnoi literatury 1918-1968. P.579-580). 
again refers to G. V. Vernadsky, to be more precise to his article "Dva podviga Aleksandra Nevskogo".

According to V.N. Il'in, N. A. Klepinin "perfectly highlighted three elements: the West which is openly hostile towards Orthodoxy... the mighty power of the East, which for a time embodied the power of Russia... and, finally, Russia, which was breaking through them and zealously protecting both its Orthodoxy and its identity as a great power" 35 .

P. N. Savitsky, one of the leading ideologists of Eurasianism, who insisted that the impact of the Tatar-Mongol yoke on the Russian history had had some positive aspects, referred to the book of N. A. Klepinin "Sviatoi i blagovernyi velikii kniaz' Aleksandr Nevskii" as well as to the study of G. V.Vernadsky "Nachertanie russkoi istorii" (The Pattern of Russian History, Prague, 1927) $)^{36}$.

N. A. Klepinin also inclined to philosophic reflection, which is attested by the extensive article published in the journal "Put" in 1927, "Mysli o religioznom smysle natsionalisma" (Reflection on the Religious Essence of Nationalism), which provided an insight into the possibility of the formation of national idea, based on religion ${ }^{37}$.

However, further rapprochement with the Eurasians encouraged N.A. Klepinin to participate more actively in their movement and engage in political issues. He attended the meetings of the Eurasianist society in Paris and gave talks there which were later covered by the Eurasian journals ${ }^{38}$. He also occasionally published his articles in these journals. For example, the $10^{\text {th }}$ issue of the "Evraziiskaia khronika" (Eurasian Chronicle), released in Paris in 1928, contains an article entitled "Rabota parizhskoi gruppy evraziitsev" (Project of the Parisian Group of Eurasians) and signed by the initial $\mathrm{K}^{39}$. There is a possibility that it was N.A. Klepinin who authored the report on the work of the group, but this is nothing more than an unchecked assumption. However, there is no doubt that his name was among the editors of the $6^{\text {th }}$ collection of articles on Eurasianism ${ }^{40}$.

In 1937, N. A. Klepinin returned to Russia. The circumstances of his homecoming were extremely dramatic for by that time he had got closely involved with the Soviet special services, which are believed to have lured him into cooperation as early as in 1933. This association resulted in the N. A. Klepinin's engagement in special operations, which led to the assassination of the defector Soviet intelligence officer Ignace Reiss and the kidnapping of E. K. Miller, the chairman of the Russian All-Military Union (RAMU) in 1937. It turned out to be impossible to cover up the second case and the organizers of the operation, including N.A. Klepinin and his spouse, were forced to flee ${ }^{41}$.

Soviet secret services quickly understood how to take advantage of Eurasianism; the officers from the organization "Trest", the creation of Cheka-OGPU (Emergency Commission-All-Russian State Political Directorate), infiltrated the circle of Eurasians back in

35 Il'in V.N. N. A. Klepinin "Sv. i blagovernyi velikii kniaz' Aleksandr Nevskii”. YMCA PRESS. Paris. str. 202 // Put.' Organ russkoi religioznoi mysli. 1927. No. 8. P. 158.

36 Savitskii P. N. Kontinent Evraziia. P. 195, 213.

37 Klepinin N.A. Mysli o religioznom smysle natsionalizma // Put'. Organ russkoi religioznoi mysli. 1927. No. 6. P.69-80.

38 Ivanov V.D. K probleme dnia // Evraziiskaia khronika. Vol. 10. Paris, 1928. P. 31.

39 K. Rabota parizhskoi gruppy evraziitsev // Evraziiskaia khronika. Vol. 10. Paris, 1928. P. 70-73.

40 Struve G. P. Russkaia literatura v izgnanii. Paris, 1984. P. 44.

${ }^{41}$ Bobrovskaia L. Brat'ia Klepininy // Studiia. 2008. No. 12. URL: http://magazines.russ.ru/studio/2008/12/bob22.html_ednref3 (accessed: 15.09.2018). 
$1923^{42}$. In 1928, S. Ia.Efron, a close friend of Klepinin's family, who would later take part both in the assassination of I.S. Reiss and kidnapping of E. K. Miller, became one of the editors of the newspaper "Eurasia"43. Thus, it is hardly surprising that some of the NKVD officers could have approached N. A. Klepinin and persuaded him to work for them.

The "surge of homecomings" was initiated by NKVD agents. However, those who returned to Russia were doomed to face a new ordeal - the horrors of GULAG and death. Unfortunately, this applied even to those émigrés who in a desperate attempt to regain their motherland assisted the representatives of the force which had taken hold of it. This is exactly what happened to S. Ia. Efron and General N. V.Skoblin, who orchestrated the kidnapping of E. K. Miller. N. A. Klepinin also did not survive this ordeal: in 1941, after the outbreak of the Great Patriotic War he and his wife were executed by shooting in the city of Orel ${ }^{44}$.

Today, half a century later, one cannot but feel sad holding the book about Alexander Nevsky written by Nikolai Andreevich when he was relatively young. Regrettably, its author could have become a great researcher and a prominent scholar, but instead ended up as an emigrant and re-emigrant, executed on a fabricated charge of espionage in favor of ... France ${ }^{45}$. N. A. Klepinin fell victim to a cruel drama which at the turn of the century divided our country into two implacable camps. The Civil War continued after the defeat of the White Army forces in Russia: the Russian All-Military Union being capable of committing targeted terrorist acts posed a threat to the Soviets. The Soviet authorities, in turn, in addition to repressions against the internal enemies (real and imaginary), responded with special operations and intrigues, which contributed to the split in the émigré circles.

There was not much hope of salvation from this turmoil of hostility and hatred; with one's countrymen being one's enemies and the apple of discord - the difference in views on social system. Nevertheless, the way out existed. It is exactly what G. V.Vernadsky, a true advocate of Eurasionism as a philosophical trend, who bitterly denounced the attempts to invest it with a kind of political air, had chosen to do. With regard to this issue in 1930 in one of his letters addressed to P. N. Savitsky, he wrote: "Eurasianism as a historico-philosophical trend, as a continuation of Slavophilism is of great importance for me [...]. At the same time, the interpretation of Eurasianism as of a political force has always been alien to me. Moreover, I am now convinced that Eurasianism with political undertones (pseudo-Eurasianism - to be precise) corrupts the great idea of true Eurasianism..." 46

It can be claimed that the rejection of political games in favor of academic pursuits allowed G. V. Vernadsky to go his own way and fulfill the great mission of establishing his own historical school, though not in his native country which got to know his works much later, but in the USA.

Another example is the life of N.A. Klepinin's younger brother Father Dmitrywho served as a priest in occupied France and was confined to the concentration camp for giving refuge to the Jews. In the concentration camp "Dora", he also made a decision to

42 Krivosheeva E. G. Porevoliutsionnoe emigrantskoe techenie evraziistvo (1921-1932). Dis. ... kand. ist. nauk. Moscow, 1995. P. 135.

43 Brossa A. Gruppovoi portret s damoi // Inostrannaia literatura. 1989. No. 12. P. 239.

${ }^{44}$ Bobrovskaia L. Brat'ia Klepininy.

45 Ibid.

46 See: Dvornichenko A. Yu. Russkii istorik Georgii Vernadskii. P. 229-230. 
identify himself with the Soviet people but did it in a different way: he cut off the French badge sewn to his prison uniform and replaced it with the emblem of a Soviet prisoner of war worn by his countrymen, which resulted in far worse conditions of detention and finally led to his death ${ }^{47}$.

Regrettably, even now in a new century and millennium, we have not cemented the split of a once united nation, united country and culture into the supporters of the "Red" and the "White"; we have failed to repair the consequences of the crazy fratricide which had swept over our ancestors a hundred years ago...

Nevertheless, focusing on the work of N.A.Klepinin, it should be emphasized that "Sviatoi i blagovernyi velikii kniaz' Aleksandr Nevskii" has been reprinted more than once lately, hence the book is still of interest to the readers, despite a variety of other publications about Alexandr Iaroslavich being released every year. This does justice to the reviewers who singled out the modest book and the talent of its author who was destined to suffer a cruel fate.

\section{References}

Begunov Yu. K. Alexander Nevsky's Choice and the Significance of the Choice for the fate of Russian Statehood Civilization. Sviatoi Aleksandr Nevskii. Sbornik statei k 760-letiiu Nevskoi bitvy, ispolniaiushchemusia v 2000 godu, ed. by Y. K. Begunov, Ust'-Izhora, [S. n.] 1999, pp. 6-17. (In Russian)

Brossa A. Group Portrait with a Lady. Inostrannaia literatura, 1989, no. 12, pp. 226-249. (In Russian)

Dvornichenko A. Yu. Russian Historian George Vernadsky. Travel in the World of People, Ideas and Events. St. Petersburg, Evraziia Publ., 2017, 724 p. (In Russian)

Fedotov G. P. Karl Marx and Alexandr Nevsky. Voprosy filosofii, 1990, no. 8, pp. 154-156. (In Russian)

Fedotov G. P. The Holy and Right-Believing Grand Prince Alexander Nevsky. YMCA PRESS, Paris. Sovremennye zapiski. Vol.36, Paris, 1928, pp. 546-549. (In Russian)

Fedotov G. P. Saints of Ancient Russia. Moscow, Moskovskii rabochii Publ., 1990, 268 p. (In Russian)

Il'in V.N. N. A. Klepinin "The Holy and Right-Believing Grand Prince Alexander Nevsky”. YMCA PRESS. Paris, p. 202. Put'. Organ russkoi religioznoi mysli, 1927, no. 8, p. 158. (In Russian)

Ivanov V.D. To the Problem of the Day. Evraziiskaia khronika, Paris, 1928, vol. 10, p. 31. (In Russian)

Klepinin D. A. Letters of Dmitry Klepinin to Shidlovskaya july 1, 1930 - March 25, 1931. Zhizn' i zhitie sviashchennika Dmitriia Klepinina. 1904-1944. Moscow, Russkii put' Publ., 2004, pp. 93-111. (In Russian)

Klepinin N. A. Brotherhood and Ways of the Orthodox Student Movement. Put'. Organ russkoi religioznoi mysli, 1926, no. 3, pp. 127-133. (In Russian)

Klepinin N.A. Thoughts on the Religious Meaning of Nationalism. Put'. Organ russkoi religioznoi mysli, 1927, no. 6, pp. 69-80. (In Russian)

Klepinin N.A. To the Memory of Abbess Catherine. Put'. Organ russkoi religioznoi mysli, 1926, no. 4. pp. 166-171. (In Russian)

Klepinin N. A. The Holy and Right-Believing Grand Prince Alexander Nevsky. Moscow, Strizhev Publ., 1993, 111 p. (In Russian)

Kostikov V. V. Let us not Curse Exile... Ways and Destinies of Russian Emigration. Moscow, Mezhdunarodnye otnosheniia Publ., 1990, 462 p. (In Russian)

Krivosheeva E. G. For Postrevolutionary Émigré Eurasianism (1921-1932). Dis. ... kand. ist. nauk. Moscow, 1995, 30 p. (In Russian)

Nasonov A.N. Mongols and Russia. History of Tatar Politics in Russia. "Russkaia zemlia" i obrazovanie territorii Drevnerusskogo gosudarstva. Istoriko-geograficheskoe issledovanie. Mongoly i Rus'. Istoriia tatarskoi politiki na Rusi. St. Petersburg, Nauka Publ., 2006, pp. 213-345. (In Russian)

Pashuto V. T. Russian Historians-Emigrants in Europe. Moscow, Nauka Publ., 1992, 398 p. (In Russian)

Savitskii P. N. The Continent of Eurasia. Moscow, Agraf Publ., 1997, 464 p. (In Russian)

Shenk F. Alexander Nevsky in Russian Cultural Memory: Saint, Ruler, National Hero (1263-2000). Moscow, Novoe literaturnoe obozrenie Publ., 2007, 592 p. (In Russian)

47 Zhizn' i zhitie sviashchennika Dmitriia Klepinina. P.29-30. 
Sokolov R. A. Alexander Nevsky in Soviet Pre-War Historiography. Aleksandr Nevskii i Ledovoe poboishche. Materialy nauchnoi konferentsii, posviashchennoi 770-letiiu Ledovogo poboishcha. Sankt-Peterburg, 7 aprelia 2012 g. / eds Y. V. Krivosheev, R. A. Sokolov. St. Petersburg, Akademiia issledovaniia kul'tury Publ., 2014, pp. 160-202. (In Russian)

Struve G.P. Russian Literature in Exile. Paris, YMCA PRESS, 1984, 419 p. (In Russian)

V.S. [N. A. Klepinin]. Zlatoust, 1992, no. 1, pp. 187. (In Russian)

Vernadskii G. V. Two Feats of Alexander Nevsky. Nash sovremennik, 1992, no. 3, pp. 151-164. (In Russian)

Vernadskii G. V. Mongolian Yoke in Russian History. Nash sovremennik, 1992, no. 3, pp. 157-164. (In Russian)

Vernadskii G. V. Mongols and Russia. Tver; Moscow, LEAN; Agraf Publ., 1997, 476 p. (In Russian)

Zander L. From the Religious Life of Russian Youth. II. Congress in Hopewe. Put'. Organ russkoi religioznoi mysli, Kn. 1. Moscow, 1992, pp. 233-234. (In Russian)

Zen’kovskii V. V. My Memories of Dmitri Klepinin. Zhizn' i zhitie sviashchennika Dmitriia Klepinina. 19041944. Moscow, Russkii put' Publ., 2004, pp. 165-170. (In Russian)

Received: December 2, 2018

Accepted: September 9, 2019

Статья поступила в редакцию 2 декабря 2018 г.

Рекомендована в печать 9 сентября 2019 г. 